REFLECTIONS:

NEUROLOGY AND THE

HUMANITIES

Section Editor

Michael H. Brooke, MD

\section{Reflections for August}

Francis O. Walker, MD

Address correspondence and reprint requests to Dr. Francis $\mathrm{O}$. Walker, Wake Forest University School of Medicine, Medical Center Blvd., Winston-Salem, NC 27157-1078 fwalker@wfubmc.edu
THE ANATOMY OF MELANCHOLY

Putting her book down, she checked her hair in the mirror and headed downstairs. She knew she could at least look forward to a good meal and a decent bottle of wine. On their way, her host for the evening toured her through the college campus. While she enjoyed the fragrant flowering of a warm spring evening and wondered to herself whether the city was always this beautiful, he repeated the travelogue his realtor had related to him.

He escorted her into the restaurant, meeting the faculty in his department already gathered at a table. Being Tuesday, it was not excessively crowded or noisy, so conversation flowed effortlessly, turning to her area of expertise, stroke, and the coordination of large clinical trials. Suggestions on how to get patients to and through the emergency room in time informed the conversation for awhile, but then talk subsided.

Already an hour past her usual suppertime, Dr. Noonan was focused on getting her entrée and dared not start on the wine while hungry. The others, well within their dietary comfort zones, indulged, while composing conversation openers in their heads. She sensed a buildup and turned to her younger host: "So, John, tell me about your new department." John, waiting for a chance to speak and fueled by his first glass of the Malbec, did not hesitate. "Well, it is unbelievable just what good fortune I have had. The University recruited me with an outstanding package and with the full blessing of the Dean, I put together a great team." She smiled politely, having herself been courted, unsuccessfully, by much larger packages. "Well," he crowed, "my first recruit has already started an autonomic testing laboratory. Endocrinology is now sending everyone with diabetic neuropathy for studies and we should be able to add another technician next year." As a mental image of a hospital lab director shaking hands with John over their coup appeared in her mind, she grinned unconsciously. John, taking this as encouragement, continued: "Not only that, she organized a monthly autonomic conference which has really inspired the third-year medical students."

Amanda, the only other woman at the table, shifted uncomfortably. As clerkship director,
Amanda knew that the case conference, conducted by a fellow, got the new recruit out of delivering formal lectures and allowed her to instead intimidate the students with questions beyond their ability. One of the students had told the new chair, John, that her method of inquisition leaned more to the Spanish than the Socratic, a comment that must have missed its mark.

Trying to change the subject, Amanda began, "Dr. Noonan, how does the Stroke Society keep track of its historical records?" Relieved by this turn in the conversation, the guest replied in detail, emphasizing the appointment of a full-time historian and a new digital image repository. Curious, she followed with, "Amanda, why do you ask?" In college, Amanda had researched the correspondence of early colonial settlers and believed that primary source material was an underused resource in the clinic. Fascinated, Dr. Noonan asked her how she thought studying historical archives compared to contemporary means of data gathering. Warmed by the shared insight, Amanda extracted the cell phone from her purse, and used it as a prop. "I encourage students to use these to call around and find reliable eyewitness accounts of events that patients cannot describe, such as strokes and seizures." John, who had been distracted by messaging on his own cell phone, took advantage of the display of both devices to compare them, deftly reinserting himself into the conversation.

In a moment, he got back to education, but on a different tack: "Amanda and I were delighted to have met with the Dean recently. Given her good work with the third-year students, I was able to convince him to assume the cost of her effort." Amanda squirmed. The gesture was not lost on the guest, who had heard from a colleague that Amanda was the last clerkship director in the institution to get departmental support. This did little to compensate her for several prior years of unfunded instructional effort.

At this point, the entrées arrived. The guest of honor set a deliberate pace, so as not to appear overly enthusiastic about the meal, and began to enjoy her wine. The conversation ebbed and flowed as the diners worked through their appetites. Hoping to share something with Amanda, she experimented with, 
"So, John, it sounds like you and the Dean are on similar wavelengths." He lit up at the perceived compliment. "Yes, the Dean is a gifted leader, a person who has his finger on the pulse of global academic medicine and so anxious to cultivate leadership skills in his new chairs." Here a subtle smile was beamed to Amanda who, distracted by her thoughts, did not notice. Dr. Noonan, too late, realized she had underestimated both Amanda's recovery time and John's aspiration to become a Dean himself.

"Why, just last week, I was complimented for being a Department Chair with so much diversity on my faculty." He numbered each category for added emphasis. Having looked over the faculty roster before arriving, Dr. Noonan knew the inflated figures represented recently appointed volunteer faculty, industry-sponsored fellows with nominal faculty positions, and undersupported but overcommitted faculty like Amanda. John, with a beatific expression, culminated his eulogy with "The Dean is simply a visionary!” Remembering her 20-second encounter with the Dean in the elevator, she interpreted his soft monotone, widened palpebral fissures, and unblinking attention in a less flattering way.

Subsequent attempts to draw out Amanda failed. Dessert was served but John declined for nutritional reasons. He assumed free reign on the conversation while the others ate and checked their watches. $\mathrm{Ca}$ sual references to known collaborators and a description of nascent success in federal funding were followed by allusions to two banner articles in prestigious journals and a handful of leadership training sessions. Dr. Noonan, less enthusiastic, thought that more wine would help with the ride back to the hotel. She had conducted similar visits to other programs to serve as a role model for young faculty, and time with self-promoting senior faculty was to be expected. On the way back, John waxed eloquent about his early years, informing her of his interest in an MBA until it was supplanted by a scholarship to medical school.

Reflux woke her late that night, probably, she decided, because of the wine. After a chalky swallow of antacid, she began to review the evening before. Experience had taught her not to resist nocturnal ruminations if she wanted to get back to sleep. Her Grand Rounds had gone well, and she knew it had resonated with a number of the residents and many of the faculty. But something about dinner had made it even less enjoyable than expected and she wondered why. Was it that John had attended too many drug company-sponsored fetes? Those rarely fostered restraint and perhaps, for John, dinner with the welldressed had a Pavlovian association with self- indulgence. She rolled onto her side, hoping this explanation would lull her back to sleep. Perhaps it worked, but the thud of the USA Today on her hotel room door induced a K-complex, rousing her out of stage 1 sleep. Her musings returned. She had just finished a stint on an editorial board and wondered if maybe there was something of the fraud about John. His big papers were from drug company studies; could it be they were ghostwritten? Well, if so, this indicated weakness but not a pervasive flaw. After all, time was short for everyone these days, and the boilerplate required by journals for major clinical trials surely left little room for creative input from investigators. Having industry-sponsored former English majors create good copy was not necessarily undesirable - she just wished one had been hired to write the manual for her new digital camera.

Then an adage describing what made a good teacher slowly wafted into consciousness: "Love the student, love the subject." She had never shared it with anyone, maybe because it was too simple and soft, but it stuck with her. Now it occurred to her what it was about her host that did not fit. John had talked of his recruits and even a few residents, so it was not his love of trainees that she found wanting, it was his love for Neurology. What she had not heard that night was talk of difficult cases, problematic diagnoses, or discussions of management - in fact, anything in which patients were the focus. Yes, there was a lot about John's self-aggrandizement that was unattractive, but that alone did not account for what was missing. What John lacked was not just love of Neurology, but love of Medicine. She had seen how want of passion in a spousal choice had diminished the lives of friends and siblings, and that of their families, and now she saw how a lack of passion for one's calling could diminish one's professional life and that of the extended family of coworkers, colleagues, and trainees. This hypothesis seemed to fit John's quest: an administrative post far from patient care. And it would explain why he could not be an engaging faculty host.

She awoke to the hotel alarm.

Tired from traveling, she sat down in her office late that day. After thumbing through her annotated book, she composed a few e-mails, beginning with a mechanical one for John thanking him for the invitation. Thinking of the mutual admiration of the Dean and his new charge, she was sorely tempted to end it with something she had just read- "Ignorance is the mother of devotion"- but dared not even type it for fear it might be sent by an errant keystroke. The e-mail for Amanda took longer. She wanted to include the advice about teaching, but realized it was unneeded. Finally, she wrote: 
Dear Amanda,

It was such a pleasure to meet you and to have the chance for an all too brief conversation. I would like to say more, but I will limit myself to simply this: When you embark on an academic career, persistence is everything. Finding what you love to do and sticking with it is a recipe for professional happiness. If you are lucky, others may someday recognize your efforts. Robert Burton, in his Anatomy of
Melancholy, says: "We can make mayors and officers every year, but not scholars." I would suggest that people like you are very much needed in your department.

-Elizabeth

Perhaps it would sustain its recipient through some tough times ahead. John, his happiness yet to be secured, seemed beyond advice.

\section{Earn Practice Management CME with AAN Audio Conferences}

The Academy is helping members take some of the confusion out of coding with a four-part series.

The 2009 Coding Audio Conferences will review proper coding in common circumstances, helping participants to code with greater precision. Upon completion, physician participants will receive 1 $\mathrm{CME}$ credit per call, up to $4 \mathrm{CME}$ credits total. Non-neurologists (e.g., practice managers) will receive a certificate of completion redeemable for credits. Special pricing is available when you register for more than one call and several people can listen in from one office-making these sessions particularly cost effective as well as educational.

For details on savings and to register, visit www.aan.com/codingcme. 


\section{Neurology}

Reflections for August

Francis O. Walker

Neurology 2009;73;483-485

DOI 10.1212/WNL.0b013e3181b16382

This information is current as of August 10, 2009

\section{Updated Information \& Services}

\section{Subspecialty Collections}

Permissions \& Licensing

Reprints including high resolution figures, can be found at: http://n.neurology.org/content/73/6/483.full

This article, along with others on similar topics, appears in the following collection(s):

\section{All Clinical Neurology}

http://n.neurology.org/cgi/collection/all_clinical_neurology

Depression

http://n.neurology.org/cgi/collection/depression

Other Education

http://n.neurology.org/cgi/collection/other_education

Professional conduct and ethics

http://n.neurology.org/cgi/collection/professional_conduct_and_ethics

Information about reproducing this article in parts (figures,tables) or in its entirety can be found online at:

http://www.neurology.org/about/about_the_journal\#permissions

Information about ordering reprints can be found online:

http://n.neurology.org/subscribers/advertise

Neurology ${ }^{\circledR}$ is the official journal of the American Academy of Neurology. Published continuously since 1951, it is now a weekly with 48 issues per year. Copyright . All rights reserved. Print ISSN: 0028-3878. Online ISSN: 1526-632X.

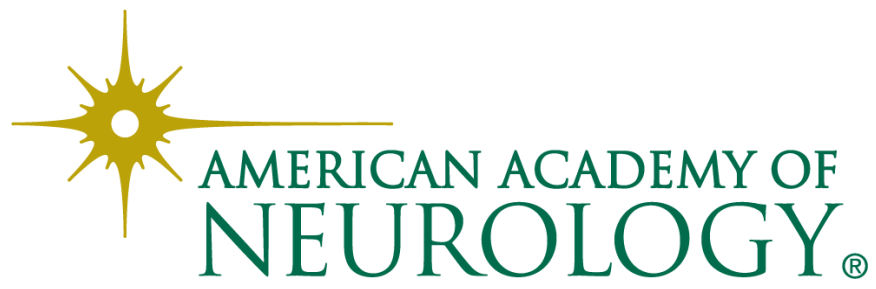

